\title{
Malaysian Public-Private Partnerships - Incentivising Private Sector Participation or Facilitating Rent-seeking?
}

\author{
R. Thillainathan ${ }^{a}$ \\ Malaysian Economic Association \\ Kee-Cheok Cheong ${ }^{\mathrm{b}}$ \\ University of Malaya
}

\begin{abstract}
While public-private collaboration can be traced to ancient times, the privatisation drive of Reagan-Thatcher, with endorsement from multilateral institutions, breathed new life into the initiative. Even as critiques were levelled at privatisation, subsequent years saw policies broadened to embrace other variations of public private partnerships (PPPs) including the private finance initiative (PFI). Countries experimenting with PPPs have come up with their own versions that differ substantially from the original implemented in the UK. Malaysia has also endorsed PPPs from its 9th Malaysia Plan, although privatisation of a fashion began even earlier. Further, Malaysia's PPPs have evolved from early privatisation to private finance initiatives (PFIs) that even more than with privatisation, are cloaked in secrecy. What little that is known, however, reveals an alarming effort to benefit the private parties. This is particularly evident in the over-pricing of contracts. From the evidence, it is hard to avoid the conclusion that Malaysia's PFI initiatives were designed to benefit vested interests at the expense of the taxpayer, while simultaneously keeping the size of the direct debt of the federal government low. Far from being the bringer of benefits as officially advertised, PFIs have been a disaster both fiscally and as instruments of rent-seeking.
\end{abstract}

Keywords: Off-budget expenditure, private finance initiative, privatisation, public-private partnership, special purpose vehicle

JEL classification: N95, O43, P35, P43, R38, R42

\section{Introduction}

From the 1980s when the Reagan and Thatcher administrations made a concerted drive towards privatisation, the shift from public to private ownership and control has spread globally, endorsed undoubtedly by multilateral institutions like the World Bank, ADB,

a Malaysian Economic Association, c/o Faculty of Economics and Administration, University of Malaya, 50603 Kuala Lumpur, Malaysia. Email: rthilli@gmail.com (Corresponding author)

b Institute of China Studies, University of Malaya, 50603 Kuala Lumpur, Malaysia. Email: cheongkeecheok@ um.edu.my

\section{Acknowledgement}

* We acknowledge with gratitude Ramesh Chander for his comments in improving the clarity of this paper, Messrs. Jeyabalan Parasingam and Alex Phang for sharing their valuable experience and expertise on the dynamics of the real estate market in Malaysia, Tan Sri Krishnan Tan and Mr SM Thanneermalai for their views on tax issues related to public private partnerships in Malaysia, and Mr P Balasundram for his assistance with the IRR calculations. We are also grateful for the very useful comments of an anonymous referee.

Article Info: Received 11 February 2019; Revised 7 May 2019; Accepted 23 May 2019

https://doi.org/10.22452/MJES.vol56no2.1 
the European Commission, ASEAN and the OECD (Hodge, Greve, \& Biygautane, 2018, p. 1108; OECD, 2013) and a sizable community of development scholars who see this as the mantra to whatever ails the public sector. However, to the extent that negatives such as lack of competition and state capture were uncovered, there was some pushback against the concept (Goodman \& Loveman, 1991).

However, even as critiques were levelled at privatisation, subsequent years saw policies broadened to embrace other variations of public private partnerships (PPPs) and in particular of the private finance initiative (PFI) or private finance alternative (PFA). Each of these initiatives holds particular attractions for government. For instance, the goal of the PFI or PFA was to improve the flexibility of public sector finances by resort to off-budget financing of projects.

At the same time, countries experimenting with such initiatives have come up with their own versions that differ substantially from the original implemented in the UK. These changes at once render the criticisms of the UK model less valid but at the same time raises the possibility that safeguards that had been built into the UK model are no longer available. Together, these factors make for the prospect that the original PFI model can morph into a variant that represents a significant improvement, or into one much worse.

This is a key question to ask in examining Malaysia's experience with PFIs, a concept it has actively embraced since the implementation of its 9th Five Year Plan (Government of Malaysia, 2006). Yet the roots of Malaysia's support for PFIs long predate this development. After a brief review of the theoretical foundations of public-private partnerships and PFIs (section 2), Malaysia's experience with PFI is the substance of section 3 . In the next section, the structure of Malaysia's involvement with PPP is discussed in the specific context of the structure of current Malaysian PFIs (section 4). In section 5, we attempt to piece together the little information on PFIs that is available in the public domain to gain insight on Malaysian PFI contracts, the potential for over-pricing and in the process understand what motivates the lack of transparency in the way these contracts work. Several cases provide confirmation that the hypothetical numbers are anchored in reality. Section 6 examines alternative scenarios that can be plausibly applied to the operation of PFI contracts. Section 7 illustrates the range of positive outcomes that concludes with lessons and thoughts for the incoming government as it tries to undo the damage inflicted by several decades of misgovernment of PFI projects.

\section{Public-Private Partnerships (PPPs) - Theoretical Framework}

Despite the current interest in PPPs, bestowed by policy-makers and critics alike, research on the interactions between the public and private sectors has had a long history (Gurgun, Polat, \& Bayhan, 2017; Mostepaniuk, 2016) with work by eminent scholars like Akerlof and Stiglitz (Estache, 2018, p. v) with whom the neoliberal label cannot be associated, that produced findings of both benefits and costs (Beuve, Saussier, \& de Brux, 2018). The extensive body of work that covered a range of projects from infrastructure to services has been categorised in terms of performance, outcomes, policy and practice (Roehrich, Lewis, \& George, 2014), 
and been implemented by a large number of governments both developed and developing. ${ }^{1}$ Yet debate on the concept has arisen because the concept has had "limited conceptualisation" (Roehrich et al., 2014) and been many things to many stakeholders, or, in the words of Hodge and Greve (2007, p. 545) "nobody seems to know precisely what they are, yet everyone is talking about them". Lack of conceptual clarity and multidimensionality has also led supporters and critics of PPP to claim success and failure by selecting whatever criteria they choose.

Even as PPPs are eagerly embraced by policy-makers attracted by benefits like increased access to funding and shifting of risks, or simply by the more positive "partnership" terminology as opposed to "privatisation", they have also galvanised critics who accuse it of being a tool of neoliberalism (Miraftab, 2004), that it has a poor performance record (never mind the mixed evidence) and that it has not benefited the public (Jomo, 2019a), promotes collusion and corruption (Jomo, 2019b).

Private finance initiatives (PFIs) represent a subset in the continuum of PPP types but no less controversial. Launched in 1992 as part of public sector reforms in the UK to reduce pressure on government budgets and lead to better value for money in public infrastructure provision (Hodge \& Greve, 2007, p. 548), its philosophical roots can be traced to the privatisation programs undertaken by the Reagan Administration in the US and by Mrs. Thatcher in the UK. Buoyed by "a period of positive economic growth and optimism" the PPP idea took off internationally from 2002 to 2007 with PPPs covering a much broader global agenda (Hodge et al., 2018, p. 1108). During this phase, PFIs have been adopted and implemented by advanced countries such as Canada, Japan, Italy, France, Germany, Korea and Australia ${ }^{2}$, as well by emerging economies like China, India, Indonesia, Malaysia and Thailand (Winch, Onishi, \& Schmidt, 2012). However, judgment as to its performance is disputed (Hodge \& Greve, 2007; SERCO, 2007; Yong, 2018). No greater clarity is offered by empirical literature reviews where examples of success and failure are found in both developed and developing economy situations (Cui, Lui, Hope, \& Wang, 2018; Sultana, Rahman, \& Chowdhury, 2013). ${ }^{3}$ Also, in reviewing largely developed country cases, Hodge and Greve (2007, p. 553) concluded that PFls have delivered "contradictory evidence as to their effectiveness".

\section{The Evolution of Malaysia's Public-Private Partnerships (PPPs)}

Privatisation as an instrument of policy by the Malaysian government can be traced to the early 1980s when an explosion of state enterprises at both the national and state level in the face of an economic recession in the mid-1980s forced upon the government the need to privatise. Although witnessing some rollback from the New

1 Gurgun et al. (2017, p. 3) used the World Bank database to report Latin America having the largest number of PPP projects in 1990-2016, followed by East Asia and the Pacific with 2,062.

2 Hodge et al. $(2018$, p. 1108) noted that Australia's early adoption of PFI was inspired by the UK experience. Canada followed in the early 2000s.

3 For instance, Bain $(2009$, p. i), in his review of PPP projects financed by the European Investment Bank (EIB), 85\% of the PPP projects were delivered within budget, in line with the UK experience, but also admitted that the EIB's reporting on cost overruns was "incomplete and suffers from inconsistencies in terms of definitions." 
Economic Policy, privatisation was consistent with Mahathir's thinking at the time (Jomo \& Tan, 2005). However, this round of privatisation was criticised for not achieving "their alleged advantages, and benefits by invoking NEP restructuring considerations, supposedly to increase Bumiputera wealth and business opportunities (but that) political influences and connections have become increasingly decisive" (Jomo \& Tan, 2005 , p. 13), the latter evidenced by the under-valuation of government assets. Even so, two policies saw the genesis of the PPP that was to be the bedrock of subsequent PFIs (Khairuddin et al., 2016, p. 113). The first policy was Malaysia Incorporated which stressed a new model in which the public sector plays the role as partner to the private sector to improve Malaysia's competitive advantage. To give substance to this cooperation, the second policy of privatisation is brought into play with the publication of the Guideline on Privatisation in 1985.

Then the 1990s saw Malaysian privatisation efforts that were part of Vision 2020 in which the private sector was to be the driving force. To this end, the privatisation policies were given a fillip with the publication of the Privatisation Master Plan 1991. But it was in the 9th Malaysia Plan (2006-2010) that PFIs came into their own. In the Plan, strategies to streamline privatisation efforts, including approval procedures, emphasising performance standards, focus on implementation and strengthening the institutional framework as well as increasing Bumiputera participation were put in place. Under the Tenth Malaysia Plan (2011-2015), the PFI concept was given a makeover with greater clarity of rules that qualified its PFI projects as "new wave" PFIs (Khairuddin et al., 2016).

Thus the modality of PPP has changed over the years from privatisation to the PFI, each with costs to stakeholders. Privatisation entailed the granting by the government of a concession to a private sector entity to takeover or build, finance and operate a business over a specified period of time and thereafter to transfer or surrender its ownership rights to the government at the end of the concession period. Electricity generation, provision of roads and supply of telecommunication services are examples of services that were now franchised by the government for provision by the private sector under its privatisation initiative over the concession period.

Under privatisation, risk is transferred from the public to the private sector in that the investing/bankruptcy risk was assumed by the franchisee as the debt incurred was typically for its own account. Privatisation also led to a decline in the level of public sector debt and hence to an improvement in government finances. The demand risk was also passed on to the franchisee. But its exposure to this risk was minimised to the extent that the privatised Malaysian activity was not fully opened up to competition. Thus, privatisation benefited the private entity more than the consumers or the economy. Further, with earlier generation privatisations, the government assumed the obligation to honour the debt liabilities of the privatised entity in the event the concessionaire was not able to operate the entity as a going concern. The benefit of this contingent liability of the government on risk sharing was enjoyed by the lender and not necessarily by the concessionaire, consumers or the economy.

Under PFI, services such as education, health care, accommodation and infrastructure services were still provided by the government but in premises or facilities some of which were constructed and financed by the private sector and whose 
ownership was to be transferred to the government, again after a specified period of time. This was deemed as a build, lease and transfer (BLT) agreement or as a build, lease, maintain and transfer (BLMT) agreement, depending on whether the premises were maintained by the private partner or the public sector.

Beyond these generalities, however, little is known about Malaysian PFIs, their contractual terms and operational guidelines shrouded in secrecy, often covered under the Official Secrets Act. Thus, unlike privatisation, the impact of PFIs on various stakeholders is not precisely known. Nor is it easy to fathom why the government moved from privatisation to PFIs. Given the deliberate efforts to shield PFIs from public scrutiny, it seems reasonable that the PFIs' lack of transparency renders them attractive for government to have PFIs cater to political objectives and/or vested interests. The ability to disguise government expenditure as off-budget items is also an attractive feature of PFIs. Also likely to be material is what Hodge and Greve's (2007) reference to PPP as a "language game" with the term PFI being more "friendly" than "privatisation" which can arouse animosity among segments of the population.

\section{PFIs with Malaysian Characteristics - Concession after Concession}

As acknowledged by numerous authors (Nooriha, Asenova, \& Bailey, 2014; Rashid, 2009), Malaysian PFIs differ from their British prototypes in important ways, all of which are to the disadvantage of the government and in favour of private entities.

A major departure is the lack of disclosure of PFI projects, which worsened the opacity which surrounds earlier efforts at privatisation but in sharp contrast to the extensive disclosure in the UK PFI prototypes. This has led Lou, Zainon, Mohd Danuri and Mohd-Rahim (2013, p. 14) to observe: "It has been years since the introduction of the PFI into construction industry, and yet little is known about exactly how the $\mathrm{PFI}$ could be used to drive the privatisation projects in Malaysia. There are neither guidelines nor regulations given to the public, and no initiative from the government to promote the scheme to private organisations. This has resulted in poor understanding, the lack of interest and minimal uptake of the PFI in the country."

This lack of disclosure, a key requirement of the UK prototypes, can be explained in terms of the difference in rationale behind the implementation of PFIs in the UK and Malaysia. Whereas full disclosure is at the heart of UK PFIs in terms of ensuring value for money and the transfer of risks commensurate with benefits derived from PFI by private interests, the motivation for Malaysian PFIs is as much to promote the objectives of the New Economic Policy (Leng, Fong, \& Sulaiman, 2007) as it is to promote the traditional objectives of "improve(ing) efficiency and productivity, facilitate economic growth, reduce the size and presence of the public sector in the economy, and to help meet the national economic policy targets" (Khairuddin et al., 2016, p. 114). This opacity thus enables the government to enter into direct negotiations with favoured parties, thus eliminating the need for competition (Nooriha, Azlinor, Asenova, \& Bailey, 2014, p. 8). ${ }^{4}$ This promotion of the NEP has ample precedent in the

4 Nooriha et al. $(2014$, p. 8) were nevertheless able to document various monitoring measures to mitigate financial and construction risks by the contracting parties. 
privatisation policies of the earlier period in which the interests of the state have been made subservient to the interests of the NEP and should not surprise.

In the Malaysian context, Khaderi and Aziz (2010, p. 109) have documented instances in which some companies have already been awarded projects under the PFI without any competitive bidding. They cite as an example the Penang Second Bridge awarded to UEM Builders Bhd under PFI without open tender, and Ekovest Bhd and Faber Group's contract to build a National Institute for Natural Products, Vaccines and Biotechnology for the Ministry of Health in a joint venture the terms of which were never disclosed and made public.

Another factor that works in the private contracting party's favour is the lack of any explicit allocation of risks in the Malaysian context between the public and the private sectors that indicate the types of risks each party needs to bear in the PPP/PFI guidelines. Nooriha et al. (2016, p. 36) noted the sharing of risk rather than risk transfer as characteristic of the allocation of risk between the government and private partners. However, they noted: "the balance between the public and private partners of those shared risks is not made clear and the government seems to have to bear all risks by default when the viability of a PPP/PFI is in jeopardy."

Nooriha et al. (2016, p. 40) who perused some PFI documentation reported that: "Some private documents ... indicated that risk transfer exists or risks are shared in $\mathrm{PPP} / \mathrm{PFI}$ projects implemented in Malaysia. However, how these risks are shared is not made clear and the government seems to have to bear all risks by default when the viability of a PPP/PFI is in jeopardy." This stands in sharp contrast to the PPP/PFI guidance from the UK which revealed clear and explicit allocation of risks between the public and the private sectors (Nooriha, et al. 2016, p. 40). To the extent that the ultimate responsibility for the operation and maintenance of a PFI project falls upon the government, there is no shifting of risk from the government to the private sector.

Selected private sector companies come from a narrow list of companies favoured by the government, typically Bumiputera private sector organisations (Nooriha et al., 2014 , p. 11), is involved only during the construction phase, but may subsequently be awarded the leasing contract by the government. As these companies acting as contractors are only involved during construction, they have no obligation in maintaining the building or provide a service. As a result, the Malaysian Ministry of Finance is required to allocate operating expenditure for maintenance of the building. There is thus no transfer of risk from the government to any private contractor who made a successful bid for the PFI contract.

A final area of concession to the private party lies in financing the PFI. Whereas private entities typically seek funding from private sources, Malaysian PFls have been funded by the Employees Provident Fund (EPF), this being the case for both Ninth and Tenth Malaysia Plan projects (Khaderi \& Aziz, 2010). ${ }^{5}$ As if this is not concessionary

5 Khaderi and Aziz (2010) reported on two government-owned special purpose vehicles (SPVs) that were formed. The first, Pembinaan BLT Sdn Bhd (BLT Sdn Bhd) was formed in 2005 to oversee the design, build, fund, lease and at the end of the concession period transfers the assets to the government to the tune of RM2 billion worth of building projects. Funding was provided by the government owned Employees Provident Fund (EPF). In 2006 and under the Ninth Malaysia Plan (9th MP, 2006-10) (Government of 
enough, an additional RM20 billion was allocated to a "facilitation" fund to "bridge the viability gap of projects", under the Tenth Malaysia Plan (10th MP, 2011-15) (Government of Malaysia, 2010). Although officially to "facilitate private sector's new investment, large scale ventures and selected privatisation and PFI projects" (UKAS, 2009), given the opacity with which PFI projects operate, there is little doubt that this fund placed at the disposal of government has the potential to be a slush fund or to be misused.

But that is not all. The use of public funds from the Employees Provident Fund (EPF), a social security organisation set up by the government to provide retirement benefits for private sector employees and non-pensionable public service employees, rather than from private financial sources from the private party, not only eliminates a key source of strength for the use of PFI but also raises questions of ethics by putting pension funds at risk. This is because since public funds are financing PFI, an important source of additional funding outside the public sector has not been tapped. And since the EPF will provide the funding for PFls, it will be the public sector rather than the private sector that takes the financing risks (Jayaseelan \& Tan, 2006, p. 106).

In terms of modality, the public sector typically enters into a build-lease-maintaintransfer (BLMT) contract under which the maintenance of the premises is for the account of the private sector partner. The choice of this mode of cooperation is also to the government's disadvantage. The government would have been better off to enter into a BLT agreement and not a BLMT agreement. This is because the BLMT partner, who is required to assume the responsibility for the upkeep and maintenance of the building on a fixed price basis over a 20- to 30-year period would want to be hedged against risks, and in particular against the risk of inflation. This being the case, the fixed price contracting period for maintenance that the government should be opting for should be for about five years or less. So long as this contract is awarded on a competitive basis, the government as a lessee will be better off and not worse off. The government, as the ultimate owner which is using the building to provide services, is better placed, in the long run, to assume the inflation risk given that it can, as the service provider, adjust the price of its service to compensate for inflation.

Thus, through modifications to the original PFI model that eliminate most of its advantages while stacking the deck in favour of favoured private interests or participants at the expense of the government and public interest, what might have been the outcome of the Malaysian PFI experience? An assessment that could have been made by the same researchers who revealed the various irregularities earlier would be expected to be damning. Instead, the adverse consequences have been swept aside. Khaderi and Aziz (2010, p. 117) concluded that "Overall, the initiative of the Malaysian government to embark on the Private Finance Initiative (PFI) for delivery of public service and facilities under the Ninth Malaysia Plan is an effective measure to overcome the maintenance problems since a long time ago. The advantages of PFI

Malaysia, 2006) another government owned SPV, Syarikat Pembinaan PFI Sdn Bhd (PFI Sdn Bhd) was formed that was given the responsibility to implement 425 projects worth RM20 billion. Funding was provided by the government owned EPF, Pension Trust Fund (PTF) and a government-linked bank, Bank Pembangunan Malaysia Berhad. 
can be fully gained if there is a firm collaboration between the government and the private sector." Nooriha et al. (2016, p. 40) justified the sharing of risk as opposed to transfer of risk in terms of its ability "to rapidly expand development of its public service infrastructures", never mind the risks to which the public sector is exposed. And despite the weaknesses attendant in the Malaysian system, Lou et al. (2013, p. 19) were able to conclude that "the Malaysian version of PFI is fundamentally at a young stage and there is no right or wrong in creating Malaysia's own version of the PFI as long as a holistic, structured and sustainable procurement solution is in place.... A Malaysian PFI can help create an economic multiplier effect that would have not been possible under the current procurement approach, given the funding constraints faced by the government." Judgments on the PFI as leading to issues of cronyism, monopolistic practices, lack of transparency in competitive bidding and lacking in experience (Rashid, 2007) seemed to be drowned by voices in support of the existing experiment.

\section{Assessing the Malaysian PFI Experience - Estimating the Over-pricing of Contracts}

The above voices of affirmation in the face of the many issues calls for more, not less, scrutiny of the Malaysian experience. This is especially because such positive assessments fly in the face of many criticisms of Malaysia's use, since the mid-1980s, of PPPs for the provision of goods and services traditionally provided by the government, that have not been carefully designed for reasons deliberate or extraneous, but have nevertheless been pushed through under a cloak of lack of transparency and which led to a great deal of controversy almost from the outset.

With the earlier privatisation initiative, the failure to use competitive bidding in the choice of a private sector partner and thereafter in opening up the privatised activity to competition, or inability to do so due to the presence of natural monopoly elements in the privatised activity, have made for these controversies or have led, more seriously, to dispute on the compensation to be paid on the cancellation of a PPP or on the takeover of a privatised asset.

The PFI has also been mired in controversy. Where a PPP was based on a land swap transaction, the underlying land value has been "invariably underpriced while the cost of the public works project is over-priced" (MOF, 2018a, p. 13). And the effective interest rate incurred by the public sector on the lease provided has also been excessive. See text below in this Section. Even worse, as a PPP's concession agreement is classified as falling within the purview of the Official Secrets Act, this may have made for the Malaysian PPP arrangement to be even more one-sided, with concerned citizens having no recourse to appeal against the government's decisions. These difficulties render the task of estimating rates of return accruing to private entities daunting. Yet, knowledge of any overestimation is an important gauge of rent extraction that is likely to have an adverse effect on growth or redistributive goals.

In the absence of PFI information disclosure, approximate benchmarks for construction, combined with plausible assumption, where needed have to be used. These benchmarks and assumptions are shown in Table 1. 
Table 1. Benchmarks and assumptions for constructing a PFI project

Mode of Operation: Build-lease-maintain-transfer (BLMT) contract

Project construction cost: RM350 million

Lease payment: RM1.1 billion over 22 years, or annual lease payment of RM50 million a year.

Effective internal rate of return (IRR) of BLMT partner: $12 \%$ per annum.

Rental yield is $5 \%$ per annum of market value of premises; maintenance charge at $20 \%$ of rental income, i.e. $1 \%$ per annum.

Compensation for private partner against tax disadvantage of having no tax allowance against chargeable income, $1 \%$ per annum.

Note: See the text below this Table on explanation and estimation of maintenance charge and of tax disallowed depreciation charge.

Source: Authors' estimates.

In Table 1, it is assumed that the government has to compensate the private contractor the annual maintenance charge and the tax disadvantage of having no tax allowance against chargeable income. The maintenance charge is not likely to exceed $1 \%$ per annum since the rental yield is not likely to exceed $5 \%$ per annum of the market value of the premises and since the average maintenance charge is likely around $20 \%$ of the rental income. At the same time, the tax disadvantage is usually substantially minimised by maximising the sum borrowed. Using straight line depreciation, and on the assumption that the mechanical and engineering works (on which the private sector can claim capital allowance) represent $20 \%$ of total building cost (with total building outlay normalised at 100), the annual depreciation charge for lease periods of 20 years and 30 years are $4 \%$ and $2.67 \%$, respectively. Taking a tax rate of $25 \%$ this implies that even for the case of the shortest lease period of 20 years, the higher tax burden from the disallowed capital allowance is no more than $1 \%$ per annum (for the case where $100 \%$ of own funds are used).

To work out the tax effect, a concrete example cited by Attorney General Tommy Thomas in his press interview (Malaysiakini and the Edge Team, 2018) can be used. In that example, the project construction cost was RM350m and total lease payments over a 22-year period was RM1.1 billion. These lease payments amount to RM50 million per annum (arrived at by dividing the total lease payments by the length of the lease period). By dividing construction cost of RM350m by 22 years, we get RM15.91 million as the sum that the BLMT builder cum financier has to receive annually as part of the lease payments to recover its upfront investment of RM350 million ${ }^{6}$.

6 This is on the understanding that the BLMT contractor has not relied on a special capital product to restructure the project payment stream to be more tax efficient by bringing forward interest payments and delaying to later years the repayment of the project's capital component. Note that where the concessions simply entailed the construction of buildings, the Inland Revenue Board ruling did not provide for any building allowance as set off against the concessionaire's chargeable income. However, with respect to infrastructure projects, such as road construction, the concessionaires were able to lobby and get the government to allow capital allowance as a chargeable tax expense based on the capital cost incurred. 
The internal rate of return (IRR) of this BLMT project is $11.6 \%$ per annum, lease payments over the 22-year lease period is RM50 million per annum and with the capital cost of RM350 million incurred over a 3-year period at RM117 million per annum. Here no account has been taken of the adverse tax effect of the BLMT arrangement ${ }^{7}$. But where the investment is in building, the tax authorities may not allow any capital allowance to be offset against the taxable income generated by the BLMT project. If the tax authorities had allowed the BLMT project owner to recoup its upfront investment of RM350 million from the lease payments receivable over the 22-year lease period, the availability of the capital allowance would have allowed the BLMT project owner to save tax on that portion of the lease payments of RM15.91 million that represented the annual charge for capital recovery. The tax savings on this would have been RM3.98 million per annum. However capital allowance is only allowed on the plant and equipment component (air conditioning, lifts, etc.) of the construction cost. If we assume that the mechanical and electrical (M\&E) component of the building cost is about $25 \%$, then the annual tax savings is only RM1 million and not RM4 million. Assuming the BLMT project owner is only able to claim $25 \%$ of its capital cost (the claimable M\&E component) the IRR of the project will be reduced to $10.8 \%$ per annum from the pre-tax IRR of $11.6 \%$ per annum.

Taking into consideration the two adverse factors with respect to the maintenance charge and tax disallowed depreciation charge, the effective interest rate earned by the BLMT partner would be reduced by about $2 \%$ to $10 \%$ per annum, for the case where the effective interest rate is taken as $12 \%$ per annum and where there is no upfront mark-up in project cost. On a 20 -year lease, this is still about $6 \%$ above the equivalent rate that the government would have incurred in funding the project over the last 10 years or so if it had chosen to do so through the issue of Malaysian Government Securities (MGS).

Where these compensating adjustments for maintenance charge and tax disallowance are lower, the government would have incurred correspondingly higher interest charges from not accessing the MGS market. This implicitly assumes that the government faced no constraint in its ability to borrow through such MGS issues, which was the case not only in the post-Asian financial crisis (AFC) period but also in the pre-AFC period from the late 1980s. ${ }^{8}$ By way of comparison, in the UK, the interest spread government entities had to bear in 2010 from resorting to private finance was estimated at between 2.0 to $3.75 \%$ per annum above the rate the UK government could have borrowed from accessing the debt market as a sovereign (NAO, 2018, p. 14).

A good example of such excesses is the Port Klang Free Zone (PKFZ) project undertaken by the Port Klang Authority (PKA), likely the first public-private partnership project in Malaysia developed and funded on a turnkey basis by a private sector entity on a BLT model a few years before the launch of the PFI in the Ninth Malaysia Plan (see

7 It is adverse to the extent that if the government alone had been involved as the builder and financier of the building, the government would not have been exposed to any tax effect.

8 There has always been a huge demand for fixed rate ringgit debt securities in Malaysia and in particular for Malaysian Government Securities from local as well as overseas institutional funds due to the country's long history of prudent and sound macroeconomic policies. These policies have made for a stable inflation and exchange rate environment. An active and liquid secondary market in MGS has provided a further boost. 
also Table 3). The award of the project on a non-competitive, deferred payment terms to KDSB, the turnkey contractor and financier, and its accelerated implementation within 2 years and not on a phased manner over 8 years (as provided for in the Port Klang Masterplan) led to a massive over-investment in capacity and cost of RM5 billion with interest cost alone accounting for $30 \%$ of that cost. In relying on private finance, the interest rate incurred by the PKFZ project was about $3.5 \%$ above what would have been incurred if it had been funded through a government guarantee. The land cost (excluding required improvements and access road) was about RM630 million above what would have been incurred if the land had been compulsorily acquired, as recommended by the Treasury and the then Attorney General. The use of the private, non-competitive route led to the outbreak of the PKFZ scandal in 2008. By then, the interest cost had ballooned to $30 \%$ of total project cost with the balance $70 \%$ land and development cost. This required a RM4.5 billion government bailout loan to avert a default. Investigations by PricewaterhouseCoopers (PwC, 2009) revealed that the interest cost associated with this bigger and longer bailout loan of RM7.5 billion would cause the project cost to further escalate to RM12.5 billion?.

The BLMT structure used subsequently by the government to finance its PPP/PFI projects is no different from that used in the PKFZ project. Its continued use post-PKFZ despite the public outcry generated by the PKFZ scandal shows that the lesson has not been learned. Indeed, under the current PPP/PFI arrangements, the situation is probably a lot worse, with the interest spread double the PKFZ level. Project cost would also have been higher, though by how much it was will only be known if there is an investigation similar to that on PKFZ.

\section{BLMT IRRs under Alternative Scenarios}

Sporadic evidence shows the effective interest rate payable by the government to its BLMT partners may be as high as $12-17 \%$ per annum. The actual IRR earned may even be higher for reasons outlined below, feeding the popular perception of significant overpricing of some contracts awarded by the government for the building of premises or infrastructure facilities due to the emergence of crony capitalism and money politics. Where there is such over-pricing, the BLMT partner's IRR can be a lot higher than the effective interest rate of $12-17 \%$ per annum. This is because the IRR will be higher since the higher is the mark-up, the higher is the share of the abnormal profits that

9 According to PwC, "the original estimated cost for the land purchase and development works in 2001 was RM1.957 billion. ... Project outlay has escalated to RM3.522 billion as at 31 December 2008. Interest cost of the deferred payments to KDSB amounted to RM1.425 billion resulting in a total Project outlay of RM4.947 billion. PKA was unable to fund its obligations to KDSB from its own resources when the first scheduled payment was due in 2007. PKA secured a 20-year soft loan of RM4.632 billion from MOF, of which RM4.382 billion is available for drawdown. This loan would impose an additional interest cost of RM2.506 billion resulting in a total Project outlay of RM7.453 billion. Cash flow projections prepared by PKA management show that PKA would be in a cumulative cash deficit position between 2012 and 2041, after paying two installments to MOF. Should PKA fail to meet the MOF soft loan installments as scheduled and if these installments are deferred to match its projected cash flows, it would incur additional interest cost of approximately RM5 billion. This would further increase the outlay of the Project to RM12.453 billion" (p. 5). The interest rate on the soft loan is $4 \%$ per annum (Lee with Lee, 2012, p. 172). 
accrue to the BLMT partner. This is easily illustrated in Table 2, in which the IRR has been computed based on an inflated or disclosed project cost and on an estimated project cost assuming that the inflated cost carries a markup of $100 \%, 50 \%, 25 \%$ and $10 \%$ over the estimated cost with the difference between the inflated and estimated cost representing the abnormal profits to be shared between the BLMT partner and the government decision-maker who awards the BLMT contract. The IRR accruing to the BLMT partner is computed on the assumption that its share of the profits is $25 \%$ and $50 \%$. With few checks and balances, the figures shown in Table 2 are well within the range of the possible. Whether it is the curse of money politics, rapacious rent-seeking or the use of a soft option to create instant businessmen in line with the New Economic Policy, the PFI system may have even permitted a markup well in excess of $100 \%$.

Ample evidence exists of BLMT contracts being awarded that guaranteed high returns not only to politically connected individuals but also to subsidiaries of GLCs (government-linked companies) such as UEM Bhd, Faber Merlin and even Sime Darby. For instance, one of the commercial arms of the University of Malaya (UM) was in discussion with one of the GLCs to build its private hospital as a BLMT project. Among the terms the GLC required was a minimum IRR of $12 \%$ per annum over the lease period, UM's guarantee as well as its first right of refusal to any future commercial development projects that UM may enter into. UM chose not to enter into such a BLMT development agreement as the terms were deemed too onerous. There are however other cases where a government entity has in fact entered into a BLMT agreement with a private sector entity where the IRR of the BLMT partner has been on the high side, the PKFZ being a good example. ${ }^{10} \mathrm{~A}$ private sector entity was the turnkey contractor to build and fund the project. As a result of the terms and manner in which the contract was awarded, it led to a public outcry in the run up to the 2008 General Election (Pua, 2011). Specifically, in relying on private finance, the interest rate incurred by the PKFZ project was about 3.5\% above what would have been incurred if it had been funded through a government guarantee. ${ }^{11}$ In the post-2006 period, the corresponding interest spread of PPP/PFI projects can be about double that of the PKFZ project.

To be fair, not all BLMT contracts entered into in Malaysia in the post-2006 period were captured by vested interests. One exception is a small BLMT contract entered into by the University of Malaya for its CIGMIT (Centre for Image Guidance and Minimally Invasive Neurosurgery) project in July 2011. Under the terms of the 10-year agreement signed, the guaranteed off-take for the services provided by the CIGMIT facility costing RM52 million only yielded a negative IRR, after taking into account maintenance charge, as the Neurosurgery Head had insisted on a comprehensive service agreement with the equipment suppliers. The BLMT partner nonetheless signed up and took the project risk on the expectation that the actual demand for the services will be a lot higher which did materialise.

10 The PKFZ project (see also Table 3) was probably the first BLT project undertaken in the country a few years before the launch of the PFI program in 2006 in the Ninth Malaysia Plan.

11 The view that the first of the BLT projects to be undertaken in Malaysia dated to the mid-1990s is incorrect in that such projects are not a public-private partnership project as its developer and financier was Putrajaya Holdings Berhad, a subsidiary of the biggest Malaysian GLCs, Petronas Berhad, which is whollyowned by the Malaysian government. 
Table 2. BLMT IRRs under alternative scenarios

\begin{tabular}{|c|c|c|c|c|c|c|c|c|c|}
\hline \multirow{3}{*}{\multicolumn{2}{|c|}{$\begin{array}{l}\text { Project cost } \\
\text { before and } \\
\text { after markup }\end{array}$}} & \multirow[t]{3}{*}{$\begin{array}{l}\text { Project cost }^{2 /} \\
\text { (normalised) }\end{array}$} & \multirow{3}{*}{$\begin{array}{l}\text { Profit } \\
\text { to } \\
\text { share }\end{array}$} & \multicolumn{4}{|c|}{$\begin{array}{l}\mathrm{IRR}^{4 /} \text { under alternative markups } \\
\text { and profit shares }{ }^{1 /}\end{array}$} & \multirow{2}{*}{\multicolumn{2}{|c|}{$\begin{array}{l}\text { All-in IRR }{ }^{3 /} \text { as } \\
\text { implied costs to } \\
\text { economy under } \\
\text { alternative } \\
\text { markups on full } \\
\text { accounting of all } \\
\text { profits shared }\end{array}$}} \\
\hline & & & & \multicolumn{2}{|c|}{$\begin{array}{l}\text { Profit share } \\
25 \%\end{array}$} & \multicolumn{2}{|c|}{$\begin{array}{l}\text { Profit share } \\
50 \%\end{array}$} & & \\
\hline & & & & $\begin{array}{l}20-y r \\
\text { lease }\end{array}$ & $\begin{array}{l}\text { 30-yr } \\
\text { lease }\end{array}$ & $\begin{array}{l}20-y r \\
\text { lease }\end{array}$ & $\begin{array}{l}30-y r \\
\text { lease }\end{array}$ & $\begin{array}{l}20-y r \\
\text { lease }\end{array}$ & $\begin{array}{l}30-y r \\
\text { lease }\end{array}$ \\
\hline \multicolumn{2}{|c|}{$\begin{array}{l}\text { Project cost } \\
\text { after markup }\end{array}$} & 100 & & & & & & & \\
\hline Project & $100 \%$ & 50 & 50 & 32.8 & 30.7 & 41.3 & 38.8 & 66.7 & 63.9 \\
\hline cost & $50 \%$ & 67 & 33 & 21.9 & 20.7 & 24.7 & 23.3 & 32.1 & 30.2 \\
\hline before & $25 \%$ & 80 & 20 & 16.8 & 16.2 & 18.0 & 17.2 & 20.6 & 19.5 \\
\hline markup of: & $10 \%$ & 91 & 9 & 13.9 & 13.6 & 14.3 & 14.0 & 15.1 & 14.7 \\
\hline
\end{tabular}

Notes: ${ }^{1 /}$ In this table, the IRR is computed on the disclosed or inflated projected cost and on the estimated project cost assuming the disclosed cost carries a mark-up of a $100 \%, 50 \%, 25 \%$ and $10 \%$ with the difference between the disclosed and estimated cost representing the abnormal profits that will be shared by the BLMT partner and the government decision-maker who awards the BLMT contract. The IRR accruing to the BLMT partner is computed on the assumption that its share of the profit is $25 \%$ and $50 \%$.

2/ The inflated or disclosed projected cost is normalised to 100 to make the cost and IRR more readily comparable under alternative scenarios with respect to markup and profit share.

3/ The all-in IRR is the implied cost to the economy of using the BLMT route for the provision of government services due to the higher cost of the private finance alternative, as well as higher markup on project cost. The bulk of the all-in IRR accrues to the BLMT partner from its profit share and annual lease payments and a part accrues to the government decision-maker as his profit share. Note that the much higher all-in IRRs associated with the disclosed or inflated costs implies a higher cost of doing business where the services provided are priced to recover full costs or the revenue shortfall from any underpricing is financed through higher taxes or borrowing.

4/ IRR of BLMT partner computed includes its share of profits.

Source: Authors' estimates.

Based on cases on which we have private information deemed reliable, we take the effective interest rate as $12 \%$ per annum as the benchmark. This is the IRR earmarked by the BLMT partner for the limiting case where the disclosed project cost is also taken as equal to its estimated cost and thus is the case where there is no abnormal profit to share. Where the lease period is 20 years, the IRR computed varies between $13.9 \%$ to $32.8 \%$ and $14.3 \%$ to $41.3 \%$ where the BLMT partner's profit share is $25 \%$ and $50 \%$ respectively and where the markup ranges from 10 to $100 \%$ (Table 2 ).

Where the lease period is 30 years, our inference with respect to the limiting case remains unchanged. But the IRR for the same markup range of $10 \%$ to $100 \%$ is only a little lower, varying from $13.6 \%$ to $30.7 \%$ per annum and $14 \%$ to $38.8 \%$ per annum for the two alternative profit share of $25 \%$ and $50 \%$ respectively (Table 2 ). 
Regardless of the lease period, what is striking are the sizes of IRRs which few businesses can aspire to achieve. Seen in this light, the orders of magnitude suggest that far from being an instrument to tap private sector resources and expertise, PFIs have become a potent instrument of rent extraction. Also because of PFIs being able to avoid fiscal scrutiny they have proved useful for the government as vehicles for offbudgeted expenditure.

The IRR previously computed is the return earned by a BLMT partner as a mark-up on the difference between the disclosed project cost and estimated actual cost with the BLMT partner's share of abnormal profit being $25 \%$ and $50 \%$. The "all-in" return which reflects the implied cost to the economy of using the BLMT route to procurement of facilities for the provision of government services is much higher thanks to the higher cost of the PFI and the higher mark-up on project cost.

This discrepancy between IRRs is clear from Table 2. For a 20-year BLMT contract, the "all-in" IRR ranges between $15.1 \%$ to $66 \%$ per annum where the project cost markup varies between $10 \%$ to $100 \%$ as compared to the corresponding IRR of the BLMT partner of between $13.9 \%$ to $32.8 \%$ per annum for the same mark-ups (where its profit share is $25 \%$ ). The higher the mark-up, the higher the "all-in" IRR and the IRR of the BLMT partner and the higher the difference between the two set of IRRs.

One additional benefit accruing to the BLMT partner bears mentioning. The lease payments the BLMT partner receives are made by the government or by a government entity. As the BLMT partner's cash flows carry the explicit or implicit obligation and balance sheet support of the government, the BLMT partner will have enjoyed a much higher borrowing capacity and incurred a much lower interest rate than if the cash flows had carried the counterparty risk of a private sector entity. The higher leveraging and the lower interest rate would have enabled the BLMT partner to enjoy a still higher return. The positive leverage effect of government counterparty risk on the BLMT partner's return can be estimated. For the initial case where there is no mark-up in project cost from lack of competitive bidding, let us take the net effective interest rate the government pays the BLMT partner as $10 \%$ per annum (i.e., net of the maintenance charge and the tax disallowed depreciation charge). Given that the counterparty risk is that of the government, the BLMT partner may only have required to inject equity of no more than $25 \%$ of the cost of construction of the premises/infrastructure facilities with the balance $75 \%$ funded by debt, and at an interest rate of $6 \%$ per annum (based on the observed rate in the debt market). On $25 \%$ of its equity its return is $10 \%$ per annum and it earns a spread of $4 \%$ per annum on the $75 \%$ debt component of its financing. This means that its actual return on equity is $22 \%$ per annum, not $10 \%$ per annum, even if it makes no upfront profit from any mark-up in project cost. For the case where the BLMT partner enjoys an upfront profit, even for the case where the mark-up is no more than $10 \%$, its return is about $14 \%$ per annum for the $100 \%$ pure equity case and $38 \%$ per annum for the case where equity is $25 \%$ and debt $75 \%$.

The consequences of the above have been clearly spelt out in Krueger (1974). Relying on her framework, the award of concessions in Malaysia under the BLMT model leads to rent-seeking not only for the much higher return the concessionaire can capture from the higher lease rental the government has been paying but also from the award of the construction contract at a mark-up above the competitively-bid cost. 
In this construction and its financing, we will be operating on a production possibility frontier that entails a trade-off between the production of a traded and non-traded good as well as between an investment in the traded and non-traded goods sectors. As the award by the public sector of the concession to the BLMT partner is on highly favourable terms, this will lead to over-investment and over- production of non-traded goods ${ }^{12}$. The resulting excess profit or rent in this activity will lead to competition among investors to use resources to actively compete for and capture the rent thus causing both investment as well as production in traded and non-traded goods to fall within the production possibility frontier as a result of the further misallocation arising from the tie up of resources in rent-seeking.

The above estimates, based on market speculation as well as on plausible scenarios inferred from a few published cases and as summarised in Table 3 represent no more than best-guess estimates of actual IRRs earned by the BLMT partners. This is the best that can be done so long as the BLMT agreements remain as classified and confidential documents although these agreements are of considerable public interest. This is despite the fact that disclosing basic information such as the lease period, the lease payable and the cost incurred in implementing a project will not in any way jeopardise the commercial interest of a BLMT partner. In fact, given the public interest nature of these projects, a case can easily be made for the release of even more information into the public domain.

Public interest is especially served if a PFI's IRR is known or can be reliably estimated. This is because the IRR can be affected by multiple factors not related to a project's economic returns. Thus, the BLMT partner's IRR will be higher than the effective interest rate if it is computed not on the disclosed but the estimated project cost and if the share of the abnormal profits accruing to the BLMT partner is higher. The likelihood of this is greater for contractors who are private individuals and companies than if the contractors are publicly-listed GLCs as the disclosure requirements are a lot more onerous for such entities. Even for GLCs, the opportunities for mark-up are higher if: (i) the contracts are awarded on a non-competitive basis, (ii) the construction of the facilities is undertaken by outside contractors, (iii) the land on which the premises or facilities are located are owned by such public-listed GLCs or they enter into such contracts through a special purpose vehicle owned jointly with private individuals or private companies.

The above raises, as a final note, the issue of Malaysia's use of special purpose vehicles (SPVs). There is nothing novel in the use of SPVs, the objective of which is to allow parent companies to meet specific objectives without impacting the entire organisation (Gosrani \& Gray, 2011, p. 2). In the decades before the onset of the global financial crisis, SPVs helped fuel robust financial growth. However, the onset of the crisis to which SPVs contributed also exposed their weaknesses through misuse and poor regulation, seeing off companies like Enron and Lehman Brothers (Gosrani \& Gray, 2011, p. 4).

12 As the concessionaires may represent a non-competing group, the restriction in competition will be such as not to make for returns in different activities to be equalised. 
In the context of developing countries, SPVs face additional challenges, not least of which is a "lack of precedents to identify (desirable) attributes of the SPV and the process is further hampered by underdeveloped financial and legal structures..." (Chowdhury \& Chen, 2010, p. 86). Lack of oversight of these entities can therefore open the door to abuses due to weak checks and balances. For Malaysia, with its track record of opacity in government contracts, SPVs can represent another instrument for "hiding identities, debts and non-productive assets... (and) to deceive investors so that they cannot judge the value and risks of the firms and investments correctly" ( $\mathrm{Na}$ 'im, 2006, p. 1). The case of Pembinaan PFI (footnote 5) is a stark example of a SPV gone wrong.

\section{Outcomes of PFI Contracts}

The most obvious outcome of the over-pricing of public works contracts in the name of leveraging private resources and expertise is the very opposite of what has been intended, allowing favoured companies to reap supernormal profits and the diversion of public resources for private benefit. The scale of such diversion and the over-pricing of contracts has come to light from scandals that are now increasingly in the public domain by virtue of the scale involved. Examples of such over-pricing are set out in Table 3 below. Since the full extent of resource diversion may never be known, these cases, astounding as they are in and of themselves, likely represent the lower bounds of the magnitude of resource diversion in the name of PFI in Malaysia.

Table 3. Select cases of the over-pricing of PFI contracts

\begin{tabular}{l|l}
\hline $\begin{array}{l}\text { Case 1: The Matrade } \\
\text { Convention \& Exhibition } \\
\text { Centre (Pua, 2011, pp. }\end{array}$ & $\begin{array}{l}\text { Hot on the heels of a "new wave of privatisation", the government } \\
\text { announced in late } 2008 \text { the construction of Malaysia's largest } \\
\text { Convention \& Exhibition Centre by the Ministry of Trade and } \\
\text { Industry (MITI). The project worth RM628 million was awarded to } \\
\text { Naza TTDI Sdn Bhd by direct negotiation in exchange for a 62.5 acre } \\
\text { or 2.8 million sq ft of prime land between Mont Kiara and Jalan } \\
\text { Duta, valued by the then MITI Minister at RM197 million (at RM72 } \\
\text { per square foot, psf) whereas a well-known valuer had put it at } \\
\text { anything between RM970 million and RM1.5 billion (i.e. at RM350 } \\
\text { to RM500 psf). The founder of Naza Group was one of the four "AP } \\
\text { Kings" in Malaysia. Together they had a monopoly of "approved } \\
\text { permits" from MITI "to import foreign cars into Malaysia and made } \\
\text { hundreds of millions of ringgit, when the scandal was exposed in } \\
\text { 2005" (Pua, 2011, pp. 167-168). The Naza Group acquired TTDI } \\
\text { Development Sdn Bhd when it went into bankruptcy during the } \\
\text { Asian financial crisis. Renamed Naza TTDI, it "made RM86 million in } \\
\text { profit on revenues of RM239 million" in 2008 (Pua, 2011, p. 167). }\end{array}$ \\
$\begin{array}{l}\text { Case 2: The Port Klang Free } \\
\text { Zone (PKFZ), a national } \\
\text { load centre and a regional } \\
\text { transshipment hub (Lee } \\
\text { with Lee, 2012; Pua, 2011, } \\
\text { \& PwC, 2009) }\end{array}$ & $\begin{array}{l}\text { Lee Hwa Beng, Chairman of Port Klang Authority (PKA) 2008-2011, } \\
\text { stated in his book that the previous boards had known all along } \\
\text { that PKA had no money to pay for the ambitious PKFZ project. } \\
\text { "Yet, PKA still entered development agreements which roughly } \\
\text { to about RM5 billion" (Lee with Lee, 2012, pp. 2-3). }\end{array}$ \\
\hline
\end{tabular}


Table 3. Continued

If PKFZ's 1,000-acre land in Pulau Indah had been compulsorily acquired, it "would have cost a total of RM442 million (i.e. RM10.16 psf) compared to the purchase price of RM1.088 billion (RM25 psf including infrastructure works with land fully reclaimed" (PwC, 2009, p. 7). KDSB, the seller of the land which had also been appointed as the turnkey developer, had earlier bought it (unimproved and unreclaimed but with half already converted for building \& industrial use) for RM96 million (at an average price of RM2.20 psf). "The land appears overpriced when compared to other transactions on the island. Industrial land in the nearby Pulau Indah Industrial Park sold for between RM19 and RM20 psf after its launch in 2000.... Later, the listed company Wijaya, KDSB's sister company, paid under RM8 psf for land next door to PKFZ in 2005" (Lee with Lee, 2012, p. 149).

The development contracts were all awarded to KDSB without competitive bids. And "contracts were entered into on the basis of estimated amounts and without detailed building plans" (PwC, 2009, p. 8), and as the terms were not subject to prior vetting by the Attorney General, "the development agreements did not follow the Public Works Department's (PWD) standard contract terms for design guarantee and defect liability" (Lee with Lee, 2012, p. 155). The value of contracts (including professional fees) awarded to KDSB amounted to RM2.393 billion whereas that to others was a mere RM41 million (Lee with Lee, 2012, p. 201). Thus, one is not surprised with PwC's statement that "PKA may not have received value for money due to its heavy reliance on KDSB as turnkey developer", that "the onus was on KDSB to deliver the completed works to PKA, with minimal supervision" and that PKA also "relied too heavily on its quantity surveyors, QS4, to verify cost estimates based on completed designs submitted by KDSB" (PwC, 2009, p. 6).

The deferred interest payments under the turnkey contract amounted to RM1.425 billion (Lee with Lee, 2012, p. 201). The interest rate payable to KDSB was $7.5 \%$ per annum. This compares unfavourably to the rate PKA would have had to pay (4\% per annum) if it had raised the required funds through the issue of government guaranteed bonds as advised by the Ministry of Finance (Pua, 2011, p. 132). Thus, the interest rate that PKA had to pay was about $3.5 \%$ higher than what it would have paid if it had issued government guaranteed bonds. The yield to maturity on KDSB issued bonds ranged between 5.25-6.15\% per annum (Lee with Lee, 2012, p. 155). This means that KDSB earned a significant spread of $1.15-2.05 \%$ per annum on the money it lent to PKA to finance the PKFZ project simply by borrowing from the market secured against the government supported deferred payments that PKA was obliged to make to KDSB that in turn had been assigned to the bond holders of the SPVs who provided the actual finance to PKA. 
Table 3. Continued

\begin{tabular}{|c|c|}
\hline & $\begin{array}{l}\text { The BLMT structure used by the government to finance its PPP/PFI } \\
\text { projects is no different from the deferred payment structure that } \\
\text { has in fact been used in the PKFZ project. Despite the PKFZ scandal, } \\
\text { the government was using the equivalent BLMT model even in } \\
\text { a more blatant manner and the spread over the equivalent MGS } \\
\text { yields are in fact a lot higher. } \\
\text { In the face of the public outcry, Lee Hwa Beng has set out in his } \\
\text { book several suits that PKA has filed "to recover claims totaling } \\
\text { RM1.6 billion which we believed to be wrongful or excess claims. } \\
\text { Among these were excess interest calculations of RM720 million } \\
\text { and wrongful claims for RM255 million involving monsoon drains } \\
\text { and water supply works. We had also sued to challenge the validity } \\
\text { of the development agreements" (Lee with Lee, 2012, pp. 235- } \\
\text { 236). }\end{array}$ \\
\hline $\begin{array}{l}\text { Case 3: } 2019 \text { Budget Speech } \\
\text { (MOF, 2018a, p. 10), "Lim: } \\
\text { Reduced cost of LRT3 } \\
\text { project will mean lower } \\
\text { fares" (Sivanandam, 2019), } \\
\text { and Renegotiation of the } \\
\text { Klang Valley mass rapid } \\
\text { transit (MRT2) project } \\
\text { (Yong, 2018). }\end{array}$ & $\begin{array}{l}\text { The extent to which public works contracts are likely to be over- } \\
\text { priced has come to light from cases that are now in the public } \\
\text { domain, the latest of which is the renegotiation of the Klang Valley } \\
\text { Mass Rapid Transit (MRT2) and LRT3 contracts in the run up to the } \\
\text { announcement of the } 2019 \text { Budget in October } 2018 \text {. In respect of } \\
\text { the } 37 \mathrm{~km} \text { LRT3 project, the new government was able to reduce } \\
\text { the cost by } 47 \% \text { from RM31.6 billion to RM16.6 billion. The Finance } \\
\text { Minister, Mr Lim Guan Eng, "gave the assurance that despite the } \\
47 \% \text { reduction, the quality of the service and the project would } \\
\text { not be compromised" (Sivanandam, 2018, p. 8). In respect of } \\
\text { the MRT2 project, which was already in an advanced stage of } \\
\text { construction, the cost was reduced by } 22.4 \% \text { from RM39.3 billion } \\
\text { to RM30.5 billion (though this entailed a slight reduction in the } \\
\text { number of stations in its network from } 35 \text { to } 33 \text { ). The willingness } \\
\text { of the contractors to agree to such massive reductions implies that } \\
\text { the original contracts were richly priced or were over-specified. } \\
\text { Looking at the difference in terms of "mark-ups", in respect of } \\
\text { LRT3, the original contract value was in fact around } 90 \% \text { higher } \\
\text { than the new renegotiated price and in respect of MRT2, the } \\
\text { increase was around } 35 \% \text {. } \\
\text { Under the terms renegotiated between the government and the } \\
\text { private contractor to undertake the construction of the MRT2 } \\
\text { project, the private contractor has undertaken to complete the } \\
\text { infrastructure project. Under the new terms, MMC Gamuda Joint } \\
\text { Venture (MMC-Gamuda) the private contractor was to complete } \\
\text { the job in February } 2014 \text { at a cost of RM28 billion, would see } \\
\text { through the completion of the above-the-ground portion at a } \\
\text { much reduced cost of RM17.42bil compared to the original cost of } \\
\text { RM22.64 billion, a } 23 \% \text { saving. That the private contractor is able } \\
\text { to shave off a quarter of the original bid speaks volumes about the } \\
\text { margin that had been built into the original bid. }\end{array}$ \\
\hline
\end{tabular}


Apart from this direct impact, it is also clear that the approaches and modalities of PPPs in Malaysia had another key goal: namely to reduce the size of public debt including by borrowing off-budget and thereby bypass the mandatory parliamentary scrutiny. The outcome has been a lack of fiscal transparency and accountability. Large contingent liabilities had been contracted hidden behind the illusion of 'responsible' fiscal policies and 'a vibrant private sector' when in reality the public sector financial position had been damaged even as the private sector remained vulnerable.

The use of off-budget borrowings by the Najib Administration to keep the size of the direct debt of the federal government low is readily apparent from the debt and liability numbers disclosed in the 2019 Budget Speech of the new Minister of Finance of the Pakatan Harapan government (Table 4). As at mid-2018, the direct debt of the federal government was RM725.2 billion (or 50.7\% of GDP) whereas the size of its committed contingent liabilities (including the unpaid portion of the 1MDB debt) was RM155.8 billion. The commitments of the federal government to make lease payments to the PPPs (including loans the government had extended to privatised entities) amounted to another RM184.9 billion. Therefore, the GDP share of the federal government's debt and liabilities was $74.5 \%$ - well in excess of the borrowing limit of $55 \%$ permitted under the law. Clearly, the Najib Administration was able to keep the federal government's borrowings within the statutory limit only because of its resort to off-budget borrowings. ${ }^{13}$ This sleigh-of-hand however does not diminish the government's debt burden; all it does is to reclassify debt that should have been what is traditionally considered as national debt.

Table 4: Debt and liabilities of federal government as of end 2017 and mid 2018

\begin{tabular}{|c|c|c|c|c|}
\hline & \multicolumn{2}{|c|}{ In billion } & \multicolumn{2}{|c|}{ As $\%$ of GDP } \\
\hline & End 2017 & Mid 2018 & End 2017 & Mid 2018 \\
\hline Federal government debt & 686.8 & 725.2 & 50.7 & 50.7 \\
\hline Committed government guarantees: & 102.1 & 117.5 & 7.5 & 8.2 \\
\hline $1 \mathrm{MDB}$ debt (net) & 38.3 & 38.3 & 2.8 & 2.7 \\
\hline Other liabilities (PPP, PFI, PLBT) $)^{1 /}$ & 260.1 & 184.9 & 19.2 & 12.9 \\
\hline TOTAL & $1,087.3$ & $1,065.9$ & 80.3 & 74.5 \\
\hline
\end{tabular}

Note: ${ }^{1 /}$ The significant difference in other liabilities between end-2017 and mid-2018 may be due to cancellation and deferment or renegotiation of contracts of certain mega-projects. There was also a reclassification of some operating expenditure into development expenditure, which may have affected the tabulation above.

Source: Ministry of Finance (2018b), 2019 fiscal outlook and federal government revenue estimates, Table 5.2, p. 126.

13 The case of Pembinaan PFI Sdn Bhd, a special purpose vehicle set up and owned by the Ministry of Finance Inc. to borrow money for the federal government, that saw its borrowings rise to RM50.2 billion, accounting for a full quarter of the federal government's committed government guarantees of RM199.1 billion (Khairie, 2018) has the makings of another scandal of a magnitude comparable to 1MDB. 


\section{Conclusion: Lessons Learned and Implications for Policy}

In a global context, Malaysia's embrace of PPPs and PFIs falls within the period when these concepts became global in the multiplicity of objectives and models of implementation. But the concept behind PPPs and PFIs that contributed massively to Malaysia's debt burden are not new to Malaysia. Building on earlier efforts at privatisation in the mid-1980s and late 1990s crises in response to the massive debt and off balance sheet public sector liabilities, Malaysia's 10th Five Year Plan to transform the economy towards high income relied heavily on the private sector as growth driver. PPPs are to be major drivers of growth. In the Plan, "the skills and expertise of the private sector in providing public services and facilities" are to be leveraged (Ali, 2009). Budget deficits are also targeted to be reduced.

Despite these objectives that are aligned with those of developed countries, Malaysia's PPP implementation bore little resemblance to the PPPs as originally conceived in the US and UK. Thus, the original objective of unburdening the public sector was not met because the government and its entities provided the funding. For this reason, no transfer of risk took place from the public to the private sector. Efficiency aspects also fell by the wayside when contracts were awarded without open tender. The exorbitant rates of return private contractors were permitted to harvest speak to efficiency not being a matter of concern in the award of contracts. And, cloaked in secrecy, the terms of negotiated PFIs were deliberately shielded from public scrutiny. These terms mostly were against the interests of the public these PFIs were supposed to serve.

Two features of Malaysia's PFIs stand out. The first is the increasing popularity of PFIs as opposed to privatisation. As virtually no information is made available by the government, the relative merits of each approach can only be guessed at. The ability to completely cloak PFI details, especially IRRs earned by favoured private contractors, and for PFI government expenditures to be completely off-budget are likely considerations. The popularity of SPVs may also stem from their lack of regulation allowing decisionmakers to bypass regulatory processes and avoid public scrutiny.

That the implementation of PFIs under the Najib Administration not only differs in substance from the earlier initiatives pioneered by the UK despite official pronouncements of common objectives but also seeks to accomplish the opposite of what is intended leads to the inevitable conclusion that Malaysia's ultimate motive for its PFIs have nothing to do with what is officially pronounced. In fact, by stacking the deck in favour of private contractors, the government had signalled the use of its PFIs as instruments for rent extraction to reward political largesse.

Given the deliberate efforts to pervert PFIs' success described above, it would be unfair to blame the failure of Malaysia's PPP/PFIs on neo-liberal ideology alone, as many critics are wont to do. Blaming PPP/PFI failure on ideology would be tantamount to not recognising the historical roots of PPP but also the multi-faceted contributions of many scholars on whom the "neo-liberal label" does not apply. Worse, it absolves those policy- and decision-makers responsible for mismanaging these initiatives. Indeed, Malaysia's experience with PPP/PFI conceptualisation and implementation suggests that while early efforts at privatisation represent some tilt toward neoliberalism as a policy 
tool, the move towards Malaysian-style PFIs, couched in greater secrecy, represents a departure from neoliberalism in the direction of kleptocracy.

With a newly elected government since May 2018, the opportunity has arisen to correct major abuses. The new administration has a 2021 time-line to issue a Fiscal Responsibility Act "that avoids reckless mega spending that entails mega debts" and to replace the current cash basis of accounting to an accrual basis to ensure the "full disclosure of our debts and liabilities as well as the value of our assets" [MOF, 2018b: 7 and 8] and a 2019 time-line to revamp the Government Procurement Act to ensure transparency and competition as well as to punish abuse of power, negligence and corruption. The MOF submitted that "open tenders will not only achieve more value for money for the taxpayers, it will also breed a more efficient and competitive private sector" (MOF, 2018b: 7). Also encouraging is the Finance Minister's 2019 Budget Speech that moving forward federal government contracts, including those under PPPs, will be awarded on the basis of open tenders and hence at a much more competitive price. And the latest initiative to launch an anti-graft plan (Idris, 2019) represent commendable first steps.

These positive signs notwithstanding, the political and social pressures that created the conditions for poor governance have not gone away. Despite the efforts of the new government, there has been scant time to root out malpractices and entrenched corruption. The marginal improvement in Transparency International's Corruption Perception Index by just a single point (from 62 out of 180 countries to 61 ) in the eight months the new PH government has been in power between 2017 to 2018 shows the challenges to improved governance the country have yet to face. And pressures remain to take advantage of opportunities for state capture and private benefit. These pressures may well force the government to backpedal on some of its promises. With a more open approach to governance that the new government has committed itself to, it falls to an invigorated civil society to police such misdemeanours so that scarce resources intended to promote growth not be diverted to enrich the politically connected.

\section{References}

Ali, S.M. (2009, October 22). More private finance initiatives to reduce budget deficits. The Star Online. Retrieved from https://www.thestar.com.my/business/business-news/2009/10/22/ more-private-finance-initiatives-to-reduce-budget-deficit/

Bain, R. (2009). Review of lessons from completed projects financed by the EIB. Kirchberg, Luxembourg: European Investment Bank.

Beuve, J., Saussier, S., \& de Brux, J. (2018). An economic analysis of public-private partnerships. In S. Saussier \& J. de Brux (Eds.), The economics of public-private partnerships: Theoretical and empirical developments (pp. 17-38). Cham, Switzerland: Springer.

Chowdhury, A.N., \& Chen, P.H. (2010). Special purpose vehicle (SPV) of public private partnership projects in Asia and Mediterranean Middle East: Trends and techniques. International Journal of Institutions and Economies, 2(1), 64-88.

Cui, C., Liu, Y., Hope, A., \& Wang, J. (2018). Review of studies on the public-private partnerships (PPP) for infrastructure projects. International Journal of Project Management, 36(5), 773794. https://doi.org/10.1016/j.jproman.2018.03.004 
Estache, A. (2018). "Foreword". In S. Saussier \& J. de Brux (Eds.), The economics of public-private partnerships: Theoretical and empirical developments (pp. v-vii). Cham, Switzerland: Springer.

Goodman, J.B., \& Loveman, G.W. (1991). Does privatization serve the public interest? Harvard Business Review (November-December). Retrieved from https://hbr.org/1991/11/doesprivatization-serve-the-public-interest

Gosrani, N., \& Gray, A. (2011). The next chapter: Creating an understanding of special purpose vehicles. London: PricewaterhouseCoopers (PwC).

Government of Malaysia. (2006). Ninth Malaysia Plan, 2006-2010. Putrajaya: Economic Planning Unit.

Government of Malaysia. (2010). Tenth Malaysia Plan, 2011-2015. Putrajaya: Economic Planning Unit.

Gurgun, A.P., Polat, G., \& Bayhan, H.G. (2017). Use of PPP in different countries and regions. In E. Pellicer, J.M. Adam, V. Yepes, A. Singh, \& S. Yazdani (Eds.), Resilient Structures and Sustainable Construction (pp. 1-6). Istanbul: ISEC Press.

Hodge, G.A., \& Greve, C. (2007). Public-private partnerships: An international performance review. Public Administration Review, 67(3), 545-558. https://doi.org/10.1111/j.15406210.2007.00736.x

Hodge, G., Greve, C., \& Biygautane, M. (2018). Do PPP's work? What and how have we been learning so far? Public Management Review, 20(8): 1105-1121. https://doi.org/10.1080/147 19037.2018.1428410

Idris, A.N. (2019, January 30). New anti-graft plan after slew of scandals. The Edge Financial Daily. Retrieved from http://www.theedgemarkets.com/article/new-antigraft-plan-after-slewscandals

Jayaseelan, R., \& Tan, M. (2006). PFI-cure for all ills? The Edge Malaysia, 72-74. Petaling Jaya: The Edge Communication Sdn Bhd.

Jomo, K.S. (2019a, April 3). Has privatization benefited the public? The Star Online. Retrieved from https://www.thestar.com.my/business/business-news/2019/04/03/has-privatisationbenefited-the-public/

Jomo, K.S. (2019b, April 24). Privatization promotes collusion and corruption, Inter Press News. Retrieved from http://www.ipsnews.net/2019/04/privatization-promotes-collusioncorruption/

Jomo. K.S., \& Tan, W.S. (2005). Privatization and renationalization in Malaysia: A survey. Paper for the Expert Group Meeting on Re-inventing Public Enterprise, October 27-28. Retrieved from http://unpan1.un.org/intradoc/groups/public/documents/un/unpan021546.pdf

Khaderi, S.S., \& Aziz, A.R.A. (2010). Adoption of private finance initiative (PFI) In Malaysian public works projects: Are we ready? Proceedings of the CIB TG72 World Building Congress (pp. 105-120). Rotterdam: Conseil International du Bâtiment.

Khairie, H.A. (2018, July 26) Cover story: A 'secret' government debt that has ballooned to RM50 billion. The Edge Markets. Retrieved from http://www.theedgemarkets.com/article/coverstory-secret-government-debt-has-ballooned-rm50-billion

Khairuddin, A.R., Sharina, F.H., Puteri, N.F., Naadia, M.F., Srazali, A., \& Azila, A.S. (2016). A review of the Malaysian public-private partnership (PPP). Journal of Scientific Research and Development, 3(4), 112-117.

Kreuger, A.O. (1974). The political economy of the rent-seeking society. The American Economic Review, 64(3), 291-303.

Lee, H.B. with Lee, S.L. (2012) PKFZ: A nation's trust betrayed. Kuala Lumpur: The Malaysian Insider.

Leng, Y.K., Fong, K., \& Sulaiman, F. (2007). Report on infrastructure financing and bond issuance in Malaysia (JBICI Research Paper No. 34). Tokyo: JBIC Institute, Japan Bank for International Cooperation. 
Lou, E., Zainon, N., Mohd Danuri, M.S., \& Mohd-Rahim, F.A. (2013). Analysis of practices for private finance initiative (PFI) procurement process: Malaysia vs United Kingdom. The Malaysian Surveyor, 48(1), 13-20.

Malaysiakini and the Edge Team. (2018, September 20). The AG wants ministers, stakeholders to help speed up law reforms. Malaysiakini. Retrieved from https://www.malaysiakini.com/ news/443852

Minister of Finance Malaysia (MOF). (2018a). 2019 budget speech. Putrajaya: Percetakan Nasional Malaysia.

Ministry of Finance. (2018b). 2019 fiscal outlook and federal government revenue estimates. Putrajaya: Percetakan Nasional Malaysia.

Miraftab, F. (2004). Public-private partnerships: The trojan horse of neoliberal development. Journal of Planning Education and Research, 24(1), 89-101. https://doi.org/10.1177/ $0739456 \times 04267173$

Mostepaniuk, A. (2016). The development of the public-private partnership concept in economic theory. Advances in Applied Sociology 6(11), 375-388. https://doi.org/10.4236/aasoci. 2016.611028

$\mathrm{Na}$ 'im, A. (2006). Special purpose vehicle institutions: Their business nature and accounting implications. Gadjah Mada International Journal of Business, 8(1): 1-19. https://doi.org/10.22146/ gamaijb.5626

National Audit Office. (2018). PFI and PF2: Report by the Comptroller and Auditor General. London: HM Treasury.

Nooriha, A., Asenova, D., \& Bailey, S.J. (2016). Risk transfer in public private partnership/private finance initiative procurement documents: The difference between the United Kingdom and Malaysia. Journal of Emerging Economies and Islamic Research, 4(Special issue), 30-42.

Nooriha, A., Azlinor, S., Asenova, D., \& Bailey, S.J. (2014). PPP/PFI in Malaysian development plans: Purpose, structure, implementation, financing and risk transfer. In Proceedings of 5th Asia-Pacific Business Research Conference 17-18 February, 2014 (pp. 1-14). Australia: World Business Institute.

Organization for Economic Cooperation and Development (OECD). (2013). Public-private partnerships in the Middle East and North Africa: A handbook for policy makers. Paris: Author.

PricewaterhouseCoopers (PwC). (2009). Position review of Port Klang Free Zone project and Port Klang Free Zone Sdn Bhd. Kuala Lumpur: Author.

Pua, T. (2011). The tiger that lost its roar: A tale of Malaysia's political economy. Petaling Jaya: Democratic Action Party.

Rashid, K.A. (2007). Private finance initiative (PFI): Concept and method of procurement for construction projects with specific reference to Malaysia. Kuala Lumpur: International Islamic University Malaysia.

Rashid, K.A. (2009). Understanding private finance initiative (PFI). Kuala Lumpur: Scholar Mind Publishing.

Roehrich, J.K., Lewis, M.A., \& George, G. (2014). Are public-private partnerships a healthy option? A systematic literature review of 'constructive' partnerships between public and private actors. Social Science \& Medicine, 113(July), 110-119. https://doi.org/10.1016/j. socscimed.2014.03.037

SERCO. (2007). PFI explained. Retrieved from http://www.serco.co.uk/images/PFIExplained-web_. pdf

Sultana, M., Rahman, A., \& Chowdhury, S. (2013). A review of performance based maintenance of road infrastructure by contracting. International Journal of Productivity and Performance Management, 62(3), 276-292. https://doi.org/10.1108/17410401311309186

Sivanandam, H. (2019, February 23). Lim: Reduced cost of LRT3 project will mean lower fares. The Star, p. 8. 
UKAS. (2009). Garispanduan kerjasama awam-swasta (Guideline on public private partnership PPP). Putrajaya: Author.

Winch, G.M., Onishi, M., \& Schmidt, S. (Eds.) (2012). Taking stock of PPPs and PFI around the world: Summary of research report 126. London: Association of Certified and Chartered Accountants.

Yong, H.K. (2018, June 8). My say: Lessons from the U.K. on the perils of PPP. The Edge Markets. Retrieved from http://www.theedgemarkets.com/article/my-say-lessons-uk-perils-ppp

Yong, Y. (2018, October 8). Cost-saving terms for MRT2 project, Star Online. Retrieved from https://www.thestar.com.my/news/nation/2018/10/08/costsaving-terms-for-mrt2-projectretender-of-transit-rail-project-works-will-save-us-rm5bil-says-li/ 